\title{
Nitrogen metabolism and urinary excretion of purines in goat kids
}

\author{
BY J, E. LINDBERG \\ Swedish University of Agricultural Sciences, Department of Animal Nutrition \\ and Management, Kungsängens gård, S.753 23 Uppsala, Sweden
}

(Received 21 September 1988 - Accepted 11 October 1988)

\begin{abstract}
1. In Expt 1 three male goat kids of the Swedish Landrace breed were bottle-fed on isoenergetic liquid diets composed of goat's milk alone or substituted with $200,400,600$ and $800 \mathrm{ml}$ of a nitrogen-free liquid diet/l. The goat kids were 3 weeks old at the start of the experiment and weighed on average $5 \cdot 3$ (SD $0 \cdot 22$ ) $\mathrm{kg}$. The experiment lasted for $45 \mathrm{~d}$ divided into nine $5 \mathrm{~d}$ periods. The goat kids were kept individually in metabolism cages, and faeces and urine were collected daily.
\end{abstract}

2. In Expt 1 there was a significant $(P<0.001)$ relation between $N$ intake and $N$ retention, with an estimated (extrapolation) basal $\mathrm{N}$ excretion of $211 \mathrm{mg} \mathrm{N} / \mathrm{kg}$ metabolic live weight $\left(\mathrm{W}^{0 \cdot 75}\right)$. While the creatinine excretion remained fairly constant $\left(19.9 \mathrm{mg} / \mathrm{W}^{0.75}\right)$, there was a tendency for both the allantoin and uric acid excretions to change with $\mathrm{N}$ intakes. Hypoxanthine showed no consistent excretion pattern, and xanthine could not be detected.

3. In Expt 2 three male goat kids of the Swedish Landrace breed were used to study the effect of level of intake on $\mathrm{N}$ and purine metabolism. The first experimental period (period 1) started at 2 weeks of age (5.5 $\mathrm{kg}$ live weight) and the second experimental period (period 2) at 9 weeks of age $(9 \cdot 8 \mathrm{~kg}$ live weight). The goat kids were bottlefed on goat milk at intended intakes of $400,600,800$ and $1000 \mathrm{~kJ}$ gross energy $/ \mathrm{kg} \mathrm{W}^{0.75}$. Each treatment was given for $7 \mathrm{~d}$ with adaptation for $3 \mathrm{~d}$ and collections for $4 \mathrm{~d}$.

4. In Expt 2 there were significant $(P<0.001)$ increases in both live weight and $\mathrm{N}$ retention when level of intake was increased. With increasing $\mathrm{N}$ intakes both total $\mathrm{N}$ and urea-N excretions increased significantly $(P<0.05)$. The proportions of urea- $\mathrm{N}$ and ammonia- $\mathrm{N}$ were fairly constant within periods, and were on average respectively 0.81 and 0.059 in period 1 and 0.84 and 0.068 in period 2. There was no significant effect of treatment on the urinary excretion of allantoin, hypoxanthine, xanthine and creatinine. In period 2 uric acid excretion was significantly $(P<0.01)$ affected by the treatments.

5. From the presented findings it is concluded that the endogenous urinary excretion of purine derivatives in a young growing ruminant was only marginally affected by large variations in protein supply, and also by the level of intake of milk.

In most mammals purines are metabolized in a series of reactions to form allantoin (Watts, 1980) through the intermediates hypoxanthine, xanthine and uric acid. Allantoin, uric acid, xanthine and hypoxanthine can all be recovered in the urine of ruminants in varying proportions depending on the nutrition of the animal.

Allantoin is the main excretion product from purine metabolism (Watts, 1980) and it was shown by Topps \& Elliot (1965) that urinary allantoin and uric acid excretion in sheep was significantly correlated with the nucleic acid concentration in rumen fluid. More recent work has confirmed a close correlation between intake of digestible dry matter or organic matter and urinary allantoin excretion in cattle (Vercoe, 1976), sheep (Antoniewicz et al. 1981) and goats (Lindberg, 1985). Direct measurements of the urinary allantoin excretion in relation to measured duodenal nucleic acid flow (Antoniewicz et al. 1980), and to abomasal infusion of microbial (Sibanda, 1982; Fujihara et al. 1987) and RNA preparations (Antoniewicz et al. 1980; Giesecke et al. 1984), have all revealed a close relation.

Although the microbial nucleic acids appear to be quantitatively most important for urinary purine excretion (Rys et al. 1975), there is also a varying contribution to the nucleic acid pool from the feed (McAllan, 1982) and from endogenous metabolism (McAllan, 1982; Lindberg, 1985). In order to use the urinary excretion of purine metabolites to quantify the intestinal microbial flow in ruminants, a better knowledge of the importance of both these nucleic acid sources is needed. In recent studies on this topic (Fujihara et al. 
1987) changes in the protein supply had little effect on the excretion of purines in the urine of ruminants.

The aim of the present work was to obtain information on the endogenous urinary excretion of purine derivatives in young ruminants when protein supply and also level of intake were varied.

\section{MATERIALS AND METHODS}

\section{Animals}

Expt 1. Three male goat kids of the Swedish Landrace breed were used. They were 3 weeks old when the experiment started and weighed on average 5.3 (SD 0.22 ) $\mathrm{kg}$.

Expt 2. Three male goat kids of the Swedish Landrace breed were used. They were 2 weeks old at the start of experimental period 1 and weighed on average 5.5 (SD 0.21$) \mathrm{kg}$. At the start of experimental period 2 they were 9 weeks old and weighed $9 \cdot 8$ (SD 0.51$) \mathrm{kg}$ on average.

\section{Feeding and diet}

Expt 1 . The kids were bottle fed three times daily at $07 \cdot 45,12 \cdot 30$ and $17 \cdot 30$ hours throughout the experiment.

The diet was composed of goat's milk alone or substituted with $200,400,600$ and $800 \mathrm{ml}$ of a nitrogen-free liquid diet/l. The $\mathrm{N}$-free liquid diet consisted of (ml/l) 186 butterfat suspension, 40 lactose, 23 mineral suspension, 1 vitamin suspension (Polymin, Ewos AB) in water. The calculated gross energy content of the diet was $3 \cdot 14 \mathrm{~kJ} / \mathrm{g}$.

The butterfat suspension was composed of (ml/1) 296 butter oil, 37 glycerol monostearate and 667 water. The mixture was heated to $75^{\circ}$ before homogenization at $80 \mathrm{~kg} / \mathrm{cm}^{2}$ (Rannie Homogenizer). The mixture was cooled immediately after homogenization to $4 \cdot 9^{\circ}$.

The mineral mixture was composed of $(\mathrm{g} / \mathrm{kg}): \mathrm{CaHPO}_{4} .2 \mathrm{H}_{2} \mathrm{O} 69 \cdot 0, \mathrm{~K}_{2} \mathrm{HPO}_{4} 68 \cdot 8$, $\mathrm{CaCl}_{2} 25 \cdot 0, \mathrm{MgSO}_{4} 28 \cdot 3, \mathrm{NaHPO}_{4} \cdot 12 \mathrm{H}_{2} \mathrm{O} 12 \cdot 5, \mathrm{NaCl} 20 \cdot 0, \mathrm{CaCO}_{3} 25 \cdot 0$, ascorbic acid 41.0, $\mathrm{FeSO}_{4} .7 \mathrm{H}_{2} \mathrm{O} 5 \cdot 2, \mathrm{MnSO}_{4} \cdot 4 \mathrm{H}_{2} \mathrm{O} 0 \cdot 13, \mathrm{ZnSO}_{4} 0 \cdot 25, \mathrm{CuSO}_{4} .5 \mathrm{H}_{2} \mathrm{O} 0 \cdot 13, \mathrm{CoCl}_{2} \cdot 6 \mathrm{H}_{2} \mathrm{O} 0 \cdot 05$, $\mathrm{KI} 0 \cdot 25, \mathrm{NaF} 0 \cdot 13$ and water to $1000 \mathrm{~g}$.

Expt 2 . The kids were bottle fed three times daily at $07.45,12.00$ and 16.00 hours with goat's milk.

\section{Experimental design}

Expt 1. The experiment lasted for $45 \mathrm{~d}$ divided into nine $5 \mathrm{~d}$ periods. The daily allowance of the liquid diet was calculated to supply $800 \mathrm{~kJ}$ gross energy (GE)/ $\mathrm{kg}$ metabolic live weight $\left(\mathrm{W}^{0.75}\right)$. The $\mathrm{N}$ intake was gradually decreased by substituting goat's milk with the $\mathrm{N}$-free liquid. The proportions of goat's milk and $\mathrm{N}$-free liquid were 100:0, 80:20, 60:40, 40:60 and 20:80 in periods 1 and 9,2 and 8,3 and 7,4 and 6 , and period 5 respectively.

The kids were weighed on the first day of each experimental period and feeding was adjusted to weight changes. Faeces and urine were collected daily.

Expt 2. There were two experimental periods; the first commenced when the kids were 2 weeks old (period 1) and the second when they were 9 weeks old (period 2).

Within-period the goat kids were allotted to four treatments according to a randomized block design. The intended treatments were $400,600,800$ and $1000 \mathrm{~kJ} \mathrm{GE} / \mathrm{kg} \mathrm{W}^{0.75}$. The $\mathrm{N}$ : energy ratio was kept constant $(1.5 \mathrm{mg} \mathrm{N} / \mathrm{kJ})$ as only milk was given.

Each treatment was given for $7 \mathrm{~d}$ with $3 \mathrm{~d}$ adaptation and collections for $4 \mathrm{~d}$. The kids were weighed on the 1 st day after the change to a new treatment.

\section{Collection of faeces and urine}

The kids were kept in metabolism crates. Faeces were collected with the aid of a harness and the urine was collected with a funnel fitted under the cage. Details of the equipment used for collections are given by Lindberg et al. $(1988 \mathrm{~b})$. 
Table 1. Expt 1.* Intake of nitrogen, faecal $N$ output and urinary excretion of total $N$, urea- $N$ and ammonia- $N$ ( $m g \mathrm{~N} / \mathrm{kg} W^{0.75}$ ) in goat kids

(Mean values with their standard errors)

\begin{tabular}{|c|c|c|c|c|c|c|c|c|c|c|c|}
\hline \multirow{3}{*}{$\begin{array}{l}\text { Experimental } \\
\text { period no. }\end{array}$} & \multirow{3}{*}{$\begin{array}{l}\text { Proportion } \\
\text { of milk }\end{array}$} & & & & & \multicolumn{6}{|c|}{ Urinary excretion } \\
\hline & & \multicolumn{2}{|c|}{$\mathbf{N}$ intake } & \multicolumn{2}{|c|}{ Faecal N } & \multicolumn{2}{|c|}{ Total N } & \multicolumn{2}{|c|}{ Urea-N } & \multicolumn{2}{|c|}{ Ammonia-N } \\
\hline & & Mean & SEM & Mean & SEM & Mean & SEM & Mean & SEM & Mean & SEM \\
\hline 1 & $1 \cdot 0$ & 1222 & $4 \cdot 7$ & 32 & $2 \cdot 0$ & 412 & $10 \cdot 3$ & 311 & $8 \cdot 8$ & 12 & 0.9 \\
\hline 2 & 0.8 & 913 & $1 \cdot 7$ & 24 & $2 \cdot 2$ & 322 & $16 \cdot 7$ & 226 & $13 \cdot 0$ & 14 & $2 \cdot 0$ \\
\hline 3 & $0 \cdot 6$ & 622 & 0.5 & 25 & $6-7$ & 268 & $11 \cdot 3$ & 172 & $8 \cdot 8$ & 15 & 1.9 \\
\hline 4 & $0 \cdot 4$ & 425 & 0.9 & 26 & $4 \cdot 9$ & 196 & $1 \cdot 1$ & 110 & 3.8 & 16 & $2 \cdot 0$ \\
\hline 5 & 0.2 & 223 & 0.8 & 40 & $1 \cdot 6$ & 179 & $13 \cdot 9$ & 89 & $9 \cdot 0$ & 20 & 42 \\
\hline 6 & $0 \cdot 4$ & 439 & $1 \cdot 1$ & 27 & $1-9$ & 235 & $14 \cdot 4$ & 126 & $4 \cdot 5$ & 18 & 0.4 \\
\hline 7 & 0.6 & 666 & 1.6 & 30 & $4-8$ & 236 & $5 \cdot 0$ & 143 & 60 & 16 & 0.6 \\
\hline 8 & 0.8 & 867 & 5.7 & 28 & 1.4 & 311 & $21 \cdot 8$ & 207 & 18.9 & 23 & 1.5 \\
\hline 9 & $1 \cdot 0$ & 1114 & 3.8 & 24 & $7 \cdot 2$ & 523 & $20 \cdot 8$ & 395 & $15 \cdot 1$ & 38 & 0.8 \\
\hline
\end{tabular}

W, live weight. * For details, see pp. 310-311.

Faeces were collected daily and freeze-dried. The urine was preserved with $100-150 \mathrm{ml}$ sulphuric acid $(100 \mathrm{ml} / \mathrm{l})$ which was added daily to the collection trays, and samples were stored at $+4^{\circ}$.

\section{Chemical analyses}

Total $\mathbf{N}$ in the liquid diets, urine and faeces was determined with a conventional macroKjeldahl method (Nordisk Metodikkommitté för livsmedel, 1976).

Ammonia was determined according to Technicon Instruments Co. Inc. (1977a) and urea with diazetylmonoxin according to Technicon Instruments Co. Inc. (1972).

Allantoin was determined by the Rimini-Schryver reaction (Young \& Conway, 1942) adapted for the AutoAnalyzer (Lindberg \& Jansson, 1988). Uric acid, hypoxanthine and xanthine were determined with reversed-phase high-pressure liquid chromatography (HPLC) using a Nova-Pak $\mathrm{C}_{18}$ column (Lindberg et al. 1988 a).

Creatinine was analysed with picric acid according to Technicon Instruments Co. Inc. $(1977 b)$.

\section{Statistical analysis}

In Expt 2 analysis of variance was made according to a randomized-block design (Dunn \& Clark, 1974) using the GLM-procedure (SAS, 1982). Between-treatment comparisons were made using the Student's $t$ test. Regression analysis was made conventionally (Dunn \& Clark, 1974).

\section{RESULTS \\ Expt 1}

Intake of energy and $N$. Due to a lower GE content in the diets given (2.89 (SD 0.070) $\mathrm{kJ} / \mathrm{g}$ ) than that calculated $(3.14 \mathrm{~kJ} / \mathrm{g})$, the energy intake was on average $724(\mathrm{SD} 7 \cdot 2) \mathrm{kJ} / \mathrm{kg}$ $\mathrm{W}^{0.75}$.

$\mathrm{N}$ intake decreased (experimental periods 1-5) and increased (experimental periods 5-9) as expected due to the substitution of goat's milk with the $\mathrm{N}$-free liquid (Table 1).

The original intention was to include a period in which only the $\mathrm{N}$-free liquid was given. A preliminary experiment, however, clearly indicated that at least $200 \mathrm{ml}$ goat's milk/l diet had to be retained to avoid problems with feed intake. 


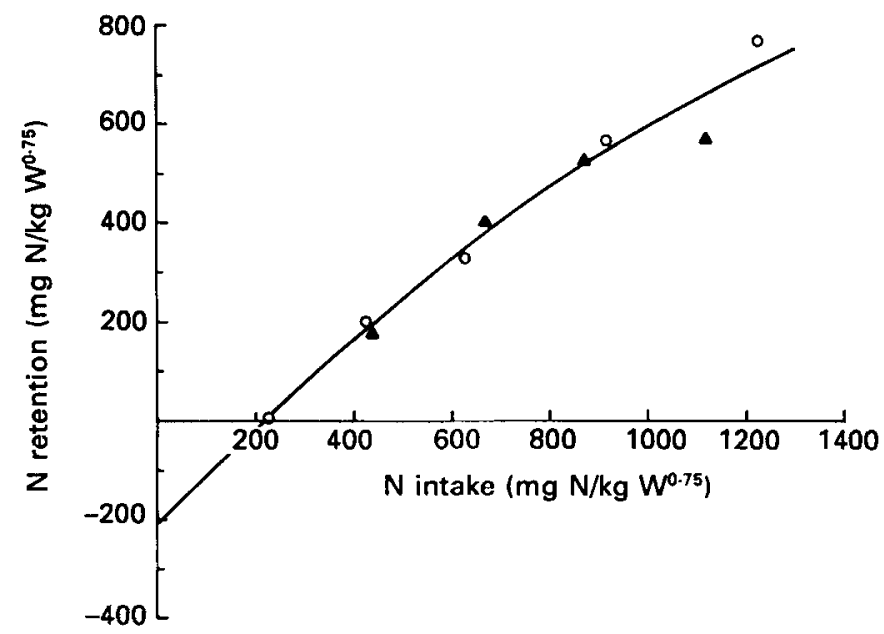

Fig. 1. Expt 1. Nitrogen retention (mg $\mathrm{N} / \mathrm{kg}$ live weight $(\mathrm{W})^{0 \cdot 75}$ ) in goat kids with decreasing $(\mathrm{O})$ and increasing (A) $\mathrm{N}$ intakes $\left(Y=-210.8+1.025 X-0.00022 X^{2} ; n 9, R^{2} 0.97\right)$. Each point represents the mean of three observations. For details of experimental procedures, see pp. 310-311.

Faecal $N$ excretion. The faecal $\mathrm{N}$ excretion was similar in all periods (27 (SE 1.02) $\mathrm{mg} \mathrm{N} /$ $\mathrm{kg} \mathrm{W}^{0.75}$ ), with a marked increase in period 5 (Table 1). For the regression, digested $\mathrm{N} v$. $\mathrm{N}$ intake, the intercept with the $Y$ axis gave an estimated endogenous faecal loss of 33 (SD 3.4) $\mathrm{mg} \mathrm{N} / \mathrm{kg} \mathrm{W}^{0.75}$. The true digestibility of $\mathrm{N}$, estimated from the regression coefficient, was $101(\mathrm{SD} 0 \cdot 7) \%$.

$N$ retention. The $\mathrm{N}$ retention was significantly $(P<0.001)$ related to $\mathrm{N}$ intake (Fig. 1$)$. The relation between $\mathrm{N}$ intake $\left(\mathrm{mg} \mathrm{N} / \mathrm{kg} \mathrm{W}^{0.75}\right)(X)$ and $\mathrm{N}$ retention $(Y)$ could be described by:

$$
Y=-210 \cdot 8+1.025 X-0.00022 X^{2} ; \quad n 9, R^{2} 0.97 .
$$

This regression was only slightly better than a linear regression. However, the curvilinear regression was chosen because with even higher $\mathrm{N}$ intakes the $\mathrm{N}$ retention could be expected to decline very markedly (Balch, 1967).

Extrapolation to zero $\mathrm{N}$ intake gives an estimate of the basal $\mathrm{N}$ requirement which was 211 (SD 72.3) $\mathrm{mg} \mathrm{N} / \mathrm{kg} \mathrm{W}^{\mathbf{0} \cdot 75}$ in this experiment. The final live weight of the kids was $8 \cdot 1$ (SD $0.56) \mathrm{kg}$ and the live weight gain was on average $61(\mathrm{SD} 7 \cdot 3) \mathrm{g} / \mathrm{d}$.

Urinary excretion of total $N$, urea- $N$ and ammonia- $N$. As expected there was a gradual reduction in total $\mathrm{N}$ and urea- $\mathrm{N}$ excretion in the urine with decreasing $\mathrm{N}$ intake and a gradual increase with increasing $\mathbf{N}$ intakes (Table 1). The ammonia excretion increased with a reduced $\mathbf{N}$ supply from the diet. When $\mathbf{N}$ supply was increased there was first a reduction in ammonia excretion, followed by a marked increase in the last two periods.

The proportion of urea- $\mathrm{N}$ decreased $(0.755,0.702,0.642,0.561$ and 0.497 in periods 1,2 , 3,4 and 5 respectively) with decreasing $N$ supply and increased $(0.536,0.606,0.666$ and 0.755 in periods $6,7,8$ and 9 respectively) with increasing $\mathrm{N}$ supply. The proportion of ammonia- $N$ increased $(0.029,0.043,0.056,0.083$ and 0.112$)$ with decreasing $N$ supply and then remained fairly constant $(0.077,0.068,0.074$ and 0.073 in periods $6,7,8$ and 9 respectively) when $\mathrm{N}$ supply increased. 


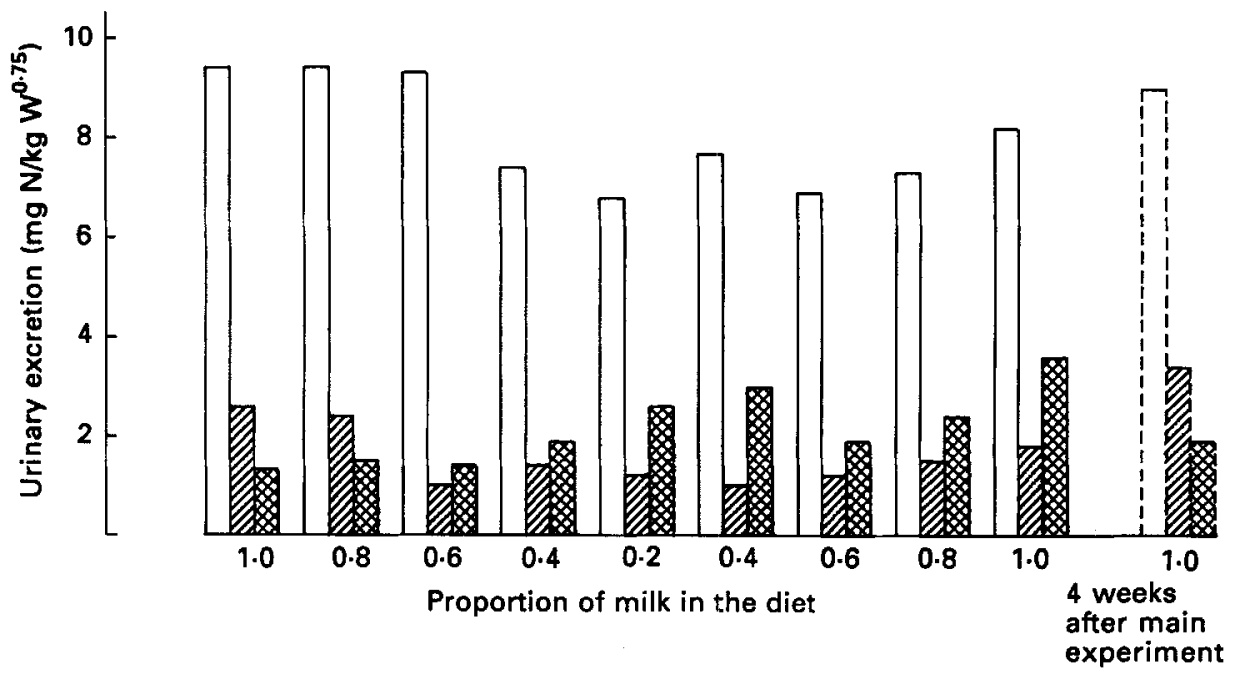

Fig. 2. Expt 1. Urinary excretion (mg nitrogen $/ \mathrm{kg}$ live weight $(\mathrm{W})^{\mathbf{0} 75}$ ) of allantoin- $\mathrm{N}$, uric acid-N and hypoxanthine- $\mathrm{N}$ in goat kids fed on different levels of $\mathrm{N}$ (for details, see pp. 310-311.) (---), Observations made 4 weeks after the main experiment, on a goat's milk diet; ( $\square$ ), allantoin-N;( $)$, uric acid-N; $(\dot{)})$, hypoxanthine-N. Values are means of three observations.

Table 2. Expt 1.* Urinary excretion of allantoin-nitrogen, uric acid- $N$, hypoxanthine- $N$ and creatinine- $N$ ( $m g ~ N / k g W^{\mathbf{0} \cdot 75}$ ) in goat kids

(Mean values with their standard errors)

\begin{tabular}{|c|c|c|c|c|c|c|c|c|c|}
\hline \multirow{2}{*}{$\begin{array}{l}\text { Experimental } \\
\text { period no. }\end{array}$} & \multirow{2}{*}{$\begin{array}{l}\text { Proportion } \\
\text { of milk }\end{array}$} & \multicolumn{2}{|c|}{ Allantoin-N } & \multicolumn{2}{|c|}{ Uric acid-N } & \multicolumn{2}{|c|}{ Hypoxanthine-N } & \multicolumn{2}{|c|}{ Creatinine- $\mathbf{N}$} \\
\hline & & Mean & SEM & Mean & SEM & Mean & SEM & Mean & SEM \\
\hline 1 & 1.0 & $9 \cdot 4$ & 0.35 & $2 \cdot 6$ & 0.03 & $1 \cdot 3$ & 0.12 & $20 \cdot 9$ & 0.15 \\
\hline 2 & 0.8 & $9 \cdot 4$ & $0 \cdot 31$ & $2 \cdot 4$ & 0.23 & 1.5 & $0 \cdot 10$ & $21 \cdot 2$ & 0.22 \\
\hline 3 & 0.6 & $9 \cdot 3$ & 0.49 & $1 \cdot 0$ & 0.03 & 1.4 & 0.35 & $20 \cdot 6$ & 0.75 \\
\hline 4 & 0.4 & $7 \cdot 4$ & 0.64 & 1.4 & 0.06 & 2.0 & 0.12 & $18 \cdot 8$ & 0.50 \\
\hline 5 & $0 \cdot 2$ & $6 \cdot 8$ & 0.41 & $1 \cdot 2$ & 0.06 & $2 \cdot 6$ & 0.80 & $19 \cdot 6$ & 0.78 \\
\hline 6 & 0.4 & 7.7 & 0.62 & 1.0 & 0.06 & 3.0 & 0.58 & 20.0 & 0.47 \\
\hline 7 & 0.6 & 6.9 & 0.42 & $1 \cdot 2$ & 0.09 & 1.9 & 0.13 & 18.6 & 0.12 \\
\hline 8 & 0.8 & $7 \cdot 3$ & 0.07 & $1 . \overline{5}$ & $0 \cdot 13$ & $2 \cdot 4$ & 0.42 & $19 \cdot 3$ & 0.58 \\
\hline 9 & 1.0 & $8 \cdot 2$ & 0.19 & 1.8 & 0.15 & $3 \cdot 6$ & 0.80 & $20 \cdot 1$ & 0.15 \\
\hline
\end{tabular}

W, live weight * For details, see pp. 310-311.

Urinary excretion of purines and creatinine. There was a tendency for the allantoin- $\mathrm{N}$ and uric acid- $\mathbf{N}$ excretion to decrease with decreasing $\mathbf{N}$ intake and then increase with increasing $\mathrm{N}$ intake (Fig. 2). This was more pronounced if observations made on the kids 4 weeks after this experiment, on the goat's-milk diet, were also taken into account. Hypoxanthine- $N$ excretion was more erratic, but was considerably higher at the end of the experiment than at the start. Xanthine could not be detected in the urine samples.

Total purines expressed as a proportion of total urinary $N$ were increased with decreasing $\mathrm{N}$ intake $(0.032,0.041,0.044,0.055$ and 0.059 in periods, $1,2,3,4$ and 5 respectively) and decreased when $N$ intake increased (0.050, 0.042, 0.036 and 0.026 in periods $6,7,8$ and 9 respectively). 
Table 3. Expt 2.* Daily intakes of gross energy (GEI) and nitrogen (NI), excretion of $N$ in faeces (FN), urine (UN), urea-N (URN) and urinary ammonia- $N$ (AMN) and $N$ retention $/ \mathrm{kg} W^{0.75}$ in goat kids; live-weight changes $(\mathrm{g} / 7 \mathrm{~d} ; \mathrm{LWC})$ during the experimental periods are also given

(Mean values with their standard errors)

\begin{tabular}{|c|c|c|c|c|c|c|c|c|c|c|c|}
\hline \multirow{2}{*}{\multicolumn{2}{|c|}{ Treatment $\dagger \ldots$}} & \multicolumn{5}{|c|}{ Period 1} & \multicolumn{5}{|c|}{ Period 2} \\
\hline & & \multirow{2}{*}{$\begin{array}{l}400 \\
386\end{array}$} & \multirow{2}{*}{$\frac{600}{570}$} & \multirow{2}{*}{$\frac{800}{738}$} & \multirow{2}{*}{$\frac{1000}{913}$} & \multirow{2}{*}{$\frac{\text { SEM }}{5.8}$} & \multirow{2}{*}{$\frac{400}{393}$} & \multirow{2}{*}{$\frac{600}{576}$} & \multirow{2}{*}{$\begin{array}{r}800 \\
754\end{array}$} & \multirow{2}{*}{$\frac{1000}{924}$} & \multirow{2}{*}{$\frac{\text { SEM }}{2 \cdot 3}$} \\
\hline GEI & $(\mathrm{kJ})$ & & & & & & & & & & \\
\hline & (mg) & 585 & 869 & 1124 & 1380 & 6.8 & 572 & 838 & 1097 & 1355 & $2 \cdot 4$ \\
\hline & (mg) & 12 & 13 & 13 & 25 & $1 \cdot 3$ & 18 & 15 & 50 & 58 & $3 \cdot 7$ \\
\hline & $(\mathrm{mg})$ & 413 & 424 & 496 & 551 & $12 \cdot 5$ & 548 & 624 & 727 & 806 & $13 \cdot 2$ \\
\hline URN & (mg) & 337 & 332 & 412 & 455 & $14 \cdot 0$ & 475 & 518 & 602 & 674 & $13 \cdot 5$ \\
\hline AMN & (mg) & 28 & 23 & 31 & 27 & 1.5 & 34 & 44 & 50 & 57 & $1 \cdot 2$ \\
\hline $\mathrm{N}$ ret & ation (mg) & 160 & 432 & 615 & 804 & 17.8 & 6 & 199 & 320 & 491 & $12 \cdot 5$ \\
\hline LWC & & -33 & 233 & 700 & 933 & 170 & -500 & 133 & 700 & 1233 & 108 \\
\hline
\end{tabular}

W, live weight. * For details, see pp. 310-311. $\dagger \mathrm{kJ}$ gross energy/kg $\mathrm{W}^{0 \cdot 75}$.

Allantoin-N, uric acid- $\mathrm{N}$ and hypoxanthine- $\mathrm{N}$ made up $0.707,0.195$ and 0.098 of the purine catabolites in period 1 . There was a tendency for the proportion of allantoin- $\mathrm{N}$ to decrease and that of hypoxanthine- $\mathrm{N}$ to increase during the experiment. The uric acid- $\mathrm{N}$ pattern was more erratic. At 4 weeks after this experiment, on the goat's-milk diet, the proportions of allantoin- $\mathrm{N}$, uric acid- $\mathrm{N}$ and hypoxanthine- $\mathrm{N}$ were $0.629,0.238$ and 0.132 respectively.

Creatinine- $\mathrm{N}$ excretion was on average $19.9(\mathrm{SE} 0 \cdot 30) \mathrm{mg} \mathrm{N} / \mathrm{kg} \mathrm{W}^{0.75}$ with no marked variation between treatments (Table 2).

\section{Expt 2}

Energy intake, $N$ intake and live-weight change. GE intakes are given in Table 3. Intakes were slightly lower than planned due to the lower GE content in the milk fed $(3.0 \mathrm{~kJ} / \mathrm{g})$ than that assumed when planning the experiment.

$\mathrm{N}$ intake increased with energy intakes, but the $\mathrm{N}$ : energy ratio was kept constant at $1.52 \mathrm{mg} \mathrm{N} / \mathrm{kJ} \mathrm{GE}$ in period 1 and at $1.46 \mathrm{mg} \mathrm{N} / \mathrm{kJ} \mathrm{GE}$ in period 2.

Live-weight changes $(\mathrm{g})$ on the different treatments $(7 \mathrm{~d})$ were significantly $(P<0.001)$ related to energy intakes. An estimate of the GE intake for zero live-weight change (maintenance) was obtained from the regression of live-weight change ( $7 \mathrm{~d}) v$. GE intakes, using the pooled values from both periods. The SEM for this estimate was obtained from separate regressions using the pooled values for each kid. Zero live-weight change was found at a GE intake of 493 (SEM 16.8) $\mathrm{kJ} / \mathrm{kg} \mathrm{W}^{0.75}$ (df 2).

Faecal $N$ excretion. Faecal $\mathrm{N}$ excretion increased significantly $(P<0.05)$ with increasing $\mathrm{GE}$ intakes in both periods 1 and 2 . The proportion of $\mathrm{N}$ apparently digested was $0.98-0.99$ in period 1 and $0.95-0.98$ in period 2.

Urinary excretion of $N$, urea- $N$ and ammonia- $N$. With increasing $\mathrm{N}$ intakes there were significant $(P<0.05)$ increases in urinary $\mathrm{N}$ and urea- $\mathrm{N}$ excretion in both periods, and also in ammonia- $\mathrm{N}$ excretion in period 2 (Table 3 ). 


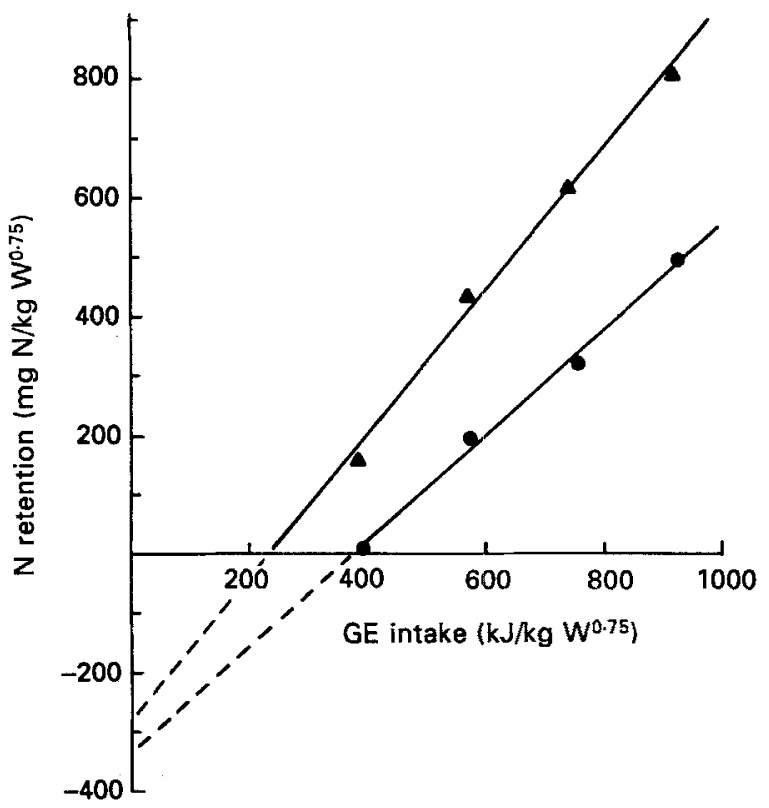

Fig. 3. Expt 2. Nitrogen retention in milk-fed goat kids at 2-6 weeks of age (period $1 ; \boldsymbol{\Delta}$ ) and at 9-13 weeks of age (period 2; $O$ ) in relation to gross energy $(\mathrm{GE})$ intake. (period $1: Y=-286 \cdot 4+1 \cdot 21 X$; $r 0.99$; period $2: Y=-335.0+0.89 X ; r 0.99$ ). Each point represents the mean of three observations. For details of experimental procedures, see pp. $310-311$. W, live weight.

The proportions of urea- $\mathrm{N}$ and ammonia- $\mathrm{N}$ in urinary $\mathrm{N}$ remained fairly constant within periods, and were on average 0.81 (SEM 0.013; df 2) and 0.059 (SEM 0.003; df 2) in period 1 , and 0.84 (SEM 0.006; df 2) and 0.068 (SEM 0.001; df 2) in period 2.

$N$ retention. With increasing energy and $\mathrm{N}$ intakes there was a highly significant $(P<0.001)$ increase in $\mathrm{N}$ retention (Table 3$)$ in both periods.

The utilization of digested $\mathrm{N}$ for body $\mathrm{N}$ accretion was markedly different in the two periods. In period 1 (between 2 and 6 weeks of age) and in period 2 (between 9 and 13 weeks of age), the proportions utilized were 0.28 and $0.01,0.50$ and $0.24,0.55$ and $0.31,0.59$ and 0.38 on treatments $400,600,800$ and $1000 \mathrm{~kJ} \mathrm{GE} / \mathrm{kg} \mathrm{W}^{0.75}$ respectively. As a consequence $\mathrm{N}$ retention was 1.21 (SEM 0.079) $\mathrm{mg} / \mathrm{kJ}$ GE intake (df $2, r 0.99$ ) in period 1 and 0.89 (SEM $0.020) \mathrm{mg} / \mathrm{kJ}$ GE intake (df $2, r 0.99$ ) in period 2 (Fig. 3).

Urinary excretion of purines and creatinine. There was no significant effect of treatments on the urinary excretion of uric acid- $\mathrm{N}$ in period 1 and of allantoin- $\mathrm{N}$, hypoxanthine- $\mathrm{N}$ and $\mathrm{xanthine}-\mathrm{N}$ in the two periods (Table 4 ). In period 2 uric acid- $\mathrm{N}$ excretion was significantly affected $(P<0.01)$ by the treatments (Table 4$)$.

Of the purines recovered in the urine the relative proportions of allantoin-N, uric acid$\mathrm{N}$, hypoxanthine- $\mathrm{N}$ and xanthine- $\mathrm{N}$ were not constant in the two periods (Table 5). The relative proportions of the purines were more variable in period 1 than in period 2 .

The treatments applied had no significant effect on creatinine- $N$ excretion (Table 4). The creatinine- $\mathrm{N}$ excretion was on average 22.2 (SEM 0.78 ) $\mathrm{mg} \mathrm{N} / \mathrm{kg} \mathrm{W}^{0.75}$ (df 2) in period 1 and 23.1 (SEM 0.70 ) $\mathrm{mg} \mathrm{N} / \mathrm{kg} \mathrm{W}^{0.75}$ (df 2) in period 2. 
Table 4. Expt 2.* Urinary excretion ( $\mathrm{mg} / \mathrm{kg} \mathrm{W}^{0.75}$ ) of allantoin- $N$, uric acid- $N$, hypoxanthine- $N$, xanthine- $N$ and creatinine- $N$ in goat kids

(Mean values with their standard errors)

\begin{tabular}{|c|c|c|c|c|c|c|c|c|c|c|}
\hline \multirow[b]{2}{*}{ Treatment $\uparrow \ldots$} & \multicolumn{5}{|c|}{ Period 1} & \multicolumn{5}{|c|}{ Period 2} \\
\hline & 400 & 600 & 800 & 1000 & SEM & 400 & 600 & 800 & 1000 & SEM \\
\hline Allantoin-N & $13 \cdot 6$ & $12 \cdot 5$ & $12 \cdot 2$ & $12 \cdot 2$ & 0.7 & $11 \cdot 4$ & $13 \cdot 3$ & $13 \cdot 2$ & $13 \cdot 6$ & 0.4 \\
\hline Uric acid-N & $7 \cdot 8$ & $3 \cdot 5$ & $2 \cdot 9$ & $4 \cdot 5$ & 0.54 & $2 \cdot 0$ & $2 \cdot 3$ & 2.9 & $2 \cdot 6$ & $0 \cdot 05$ \\
\hline Hypoxanthine-N & 1.6 & $1 \cdot 1$ & $1 \cdot 4$ & $1 \cdot 2$ & $0 \cdot 11$ & $1 \cdot 7$ & 1.9 & $1 \cdot 8$ & 1.6 & $0 \cdot 11$ \\
\hline Xanthine-N & $0 \cdot 2$ & $0 \cdot 2$ & $0 \cdot 3$ & $0 \cdot 2$ & 0.02 & $0 \cdot 1$ & $0 \cdot 2$ & $0 \cdot 2$ & $0 \cdot 1$ & 0.02 \\
\hline Creatinine-N & $21 \cdot 3$ & 21.9 & $23 \cdot 1$ & $22 \cdot 5$ & $0 \cdot 4$ & $22 \cdot 1$ & $23 \cdot 3$ & $24 \cdot 0$ & $23 \cdot 3$ & $0 \cdot 3$ \\
\hline
\end{tabular}

* For details, see pp. 310-311. † kJ gross energy $/ \mathrm{kg} \mathrm{W}^{0 \cdot 75}$.

Table 5. Expt 2.* Average proportions of allantoin-nitrogen, uric acid- $N$, hypoxanthine- $N$ and xanthine- $N$ of total purines recovered in the urine of goat kids

\begin{tabular}{|c|c|c|c|c|c|c|c|c|}
\hline \multirow[b]{2}{*}{ Treatment $\uparrow \ldots$} & \multicolumn{4}{|c|}{ Period 1} & \multicolumn{4}{|c|}{ Period 2} \\
\hline & 400 & 600 & 800 & 1000 & 400 & 600 & 800 & 1000 \\
\hline Allantoin- $N$ & 0.536 & 0.723 & 0.726 & 0.674 & 0.750 & 0.751 & 0.729 & 0.760 \\
\hline Uric acid-N & 0.336 & 0.202 & 0.173 & 0.249 & $0 \cdot 132$ & 0.130 & $0 \cdot 160$ & 0.145 \\
\hline Hypoxanthine-N & 0.069 & 0.064 & 0.083 & 0.066 & $0 \cdot 112$ & $0 \cdot 107$ & 0.099 & 0.089 \\
\hline Xanthine-N & 0.008 & 0.012 & 0.018 & 0.011 & 0.007 & 0.011 & 0.011 & 0.006 \\
\hline
\end{tabular}

* For details, see pp. 310-311. $\dagger \mathrm{kJ}$ gross energy $/ \mathrm{kg} \mathrm{W}^{0.75}$.

\section{DISCUSSION \\ Energy and $N$ intakes and utilization}

When energy intake is kept at a constant level, $\mathbf{N}$ retention is closely related to $\mathrm{N}$ intakes (Balch, 1967; Ørskov \& MacLeod, 1982; Storm et al. 1983); this was confirmed in Expt 1 .

With increasing intakes of energy and $\mathbf{N}$ (Expt 2) there was a significant increase in live weight and $\mathrm{N}$ retention $(P<0.001)$. There was, however, a marked difference in the utilization of digested $N$ in period 1 (2-6 weeks of age) and period 2 (9-13 weeks of age) as shown in Fig. 4. Due to differences in the utilization of digested $\mathbf{N}$ the kids retained $1.21 \mathrm{mg} \mathrm{N} / \mathrm{kJ} \mathrm{GE}$ at $2-6$ weeks of age compared with $0.89 \mathrm{mg} \mathrm{N} / \mathrm{kJ} \mathrm{GE}$ at $9-13$ weeks of age. This finding is in agreement with the general change in protein and fat content of empty-body-weight gain with advancing maturity (Agricultural Research Council, 1980). As more fat than protein is deposited per $\mathrm{kg}$ live-weight gain (Agricultural Research Council, 1980; McGregor, 1980) with increasing live weight, less energy is available for protein deposition. On average, zero live-weight change was found at $493 \mathrm{~kJ} \mathrm{GE}$ intake $/ \mathrm{kg}$ $\mathrm{W}^{0.75}$. With an energy digestibility of 0.96 and urinary energy losses of $10 \%$ digested energy (Lindgren, 1980) the metabolizable energy requirement for maintenance was $426 \mathrm{~kJ} / \mathrm{kg}$ $\mathrm{W}^{0.75}$ per $\mathrm{d}$. This compares well with maintenance estimates for liquid-fed calves, given by the Aricultural Research Council (1980). In milk-fed young lambs Walker \& Faichney $(1964 b)$ obtained a fasting metabolic rate of $425 \mathrm{~kJ} \mathrm{ME} / \mathrm{kg} \mathrm{W}^{0.75}$ per d.

It should also be noted that despite a negative energy balance at the lowest level of intake 


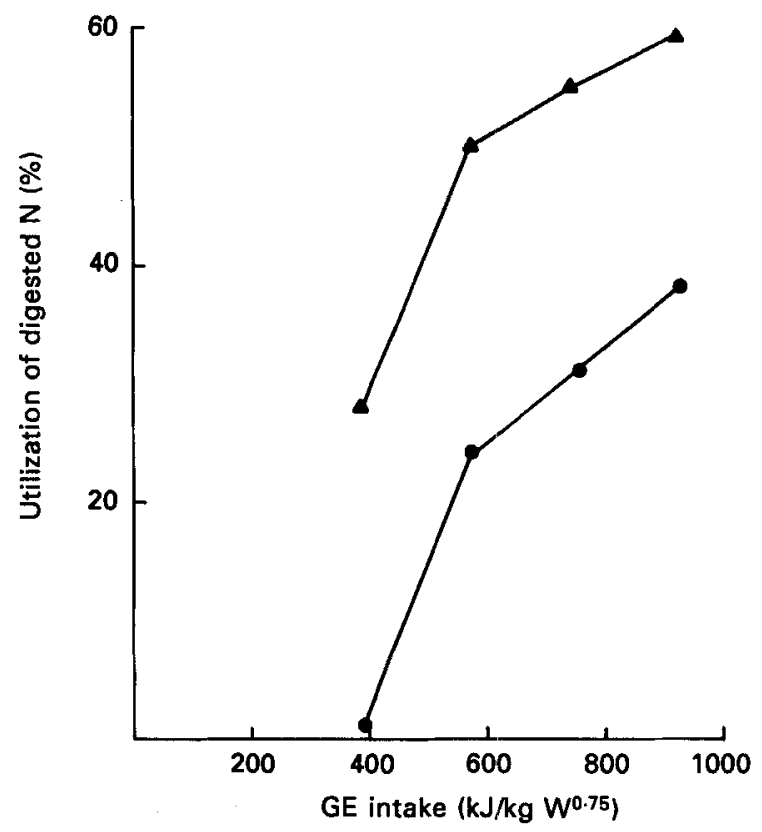

Fig. 4. Expt 2. Utilization of digested nitrogen (\%) in milk-fed goat kids at 2-6 weeks of age (period 1; $\Delta$ ) and at 9-13 weeks of age (period 2;O) in relation to gross energy (GE) intake. Each point represents the mean of three observations. For details of experimental procedures, see pp. 310-311. W, live weight.

(approximately $390 \mathrm{~kJ} \mathrm{GE} / \mathrm{kg} \mathrm{W}^{0.75}$ ) in both periods in Expt 2, the $\mathrm{N}$ retention was positive. Similar observations have been made both in sheep (Hovell et al. 1983 b) and in cattle (Ørskov et al. 1983). Although it is well established that $\mathrm{N}$-balance experiments tend to overestimate $\mathrm{N}$ retention, due to errors in the procedure, it cannot be established to what extent this has affected the values given. This might have contributed to the apparently positive $\mathrm{N}$ retention at the lowest level of energy intake. However, as shown in Table 3 and Fig. 3, the values presented suggest that $\mathrm{N}$ accretion has a priority over fat deposition in general, and more so in a young animal with a high protein requirement. This also shows that $\mathbf{N}$ can be retained despite substantial weight losses, which is in agreement with the results of Fattet et al. (1984).

In Expt 1 the faecal $\mathrm{N}$ excretion was on average 27 (SEM 1.02) $\mathrm{mg} / \mathrm{kg} \mathrm{W}^{0.75}$, which was comparable to values obtained in cows $\left(24-25 \mathrm{mg} / \mathrm{kg} \mathrm{W}^{0.75}\right.$; Ørskov \& McLeod, 1982; Ørskov et al. 1983) and steers ( $32 \mathrm{mg} / \mathrm{kg} \mathrm{W}^{0 \cdot 75}$; Ørskov et al. 1983) sustained on intragastric infusion of nutrients with casein as the protein source. The true digestibility of milk protein of 1.0 found in these experiments has also been found in lambs infused with casein in the abomasum (Hovell et al. $1983 \mathrm{~b}$ ).

At $\mathrm{N}$ intakes from $600 \mathrm{mg}$ to $1400 \mathrm{mg} / \mathrm{kg} \mathrm{W}^{0.75}$ (Expt 1), $0.57 \mathrm{~kg} / \mathrm{kg}$, on average, was retained. Storm et al. (1983) found that $\mathrm{N}$ from rumen micro-organisms infused into the abomasum was utilized with an efficiency of 0.54 .

The estimated basal $\mathrm{N}$ requirement $\left(211 \mathrm{mg} / \mathrm{kg} \mathrm{W}^{0.75}\right)$ found in Expt 1 was slightly lower than the estimated $\mathrm{N}$ requirement of lactating goats $\left(229 \mathrm{mg} / \mathrm{kg} \mathrm{W}^{0.75}\right)$ of the same breed extrapolated from balance values (Ciszuk \& Lindberg, 1985). The basal N requirement of the kids was comparable with basal urinary $\mathrm{N}$ losses from giving $\mathrm{N}$-free liquid diets to calves $\left(194 \mathrm{mg} / \mathrm{kg} \mathrm{W}^{\mathbf{0} 75}\right.$; Blaxter \& Wood, 1951) and lambs $\left(190 \mathrm{mg} / \mathrm{kg} \mathrm{W}^{0 \cdot 75}\right.$; Walker \& 
Faichney, 1964a). Considerably higher total $\mathrm{N}$ excretion values were obtained in cows, steers and lambs sustained on intragastric infusion of nutrients (Ørskov \& MacLeod, 1982; Hovell et al. 1983a; Ørskov et al. 1983; Storm et al. 1983). It is not possible to resolve whether this discrepancy was due to species differences or to the methods used in determining basal $\mathrm{N}$ requirements. One possible explanation could be the level of energy intake used in Expt $1\left(724 \mathrm{~kJ} \mathrm{GE} / \mathrm{kg} \mathrm{W}^{0.75}\right)$ compared with the energy intakes (about $450 \mathrm{~kJ} \mathrm{GE} / \mathrm{kg} \mathrm{W}^{\mathbf{0} 75}$ ) used in the infusion experiments (Ørskov \& MacLeod, 1982; Hovell et al. $1983 a$; Ørskov et al. 1983) where the basal $\mathrm{N}$ requirements have been estimated. It has been shown (Ørskov \& MacLeod, 1982), both in dry cows and in steers, that there was a substantial decrease in total $\mathrm{N}$ excretion when energy intakes (as volatile fatty acids) were increased.

Another important difference between $\mathrm{N}$-balance studies with $\mathrm{N}$-free liquid diets and with intragastric infusion of nutrients is the supply of energy-yielding nutrients. In the Nfree liquid diets used in the present study, energy came from both triglycerides and lactose, while in the intragastric infusion experiments referred to previously, short-chain fatty acids provided all the energy. With direct supply of glucose the need to metabolize tissue protein would be expected to decrease and, as a consequence, reduce the endogenous $\mathrm{N}$ loss.

\section{Urinary excretion of urea and ammonia}

When only goat's milk was given (Expt 1, periods 1 and 9) the proportion of urea- $\mathrm{N}$ was 0.75 and that of ammonia- $\mathrm{N}$ was 0.029 (period 1 ) and 0.073 (period 9). With decreasing $\mathrm{N}$ intake the proportion of urea- $\mathrm{N}$ decreased, while that of ammonia- $\mathrm{N}$ increased, as also found in lambs (Walker \& Faichney, 1964a), but at the same time the analysed $\mathrm{N}$ component as a proportion of total urinary $\mathrm{N}$ decreased from 0.87 to 0.70 . The reason for this is not known at present.

In cows and steers (Ørskov \& MacLeod, 1982) also, the proportion of urea- $\mathrm{N}$ decreased with decreasing urinary $\mathrm{N}$ excretions.

The ratio, urea- $\mathrm{N}$ : ammonia- $\mathrm{N}$ in the urine remained fairly constant in the two experimental periods in Expt 2, despite changes in live weight and $\mathrm{N}$ retention. This was in contrast to Expt 1, where the ratio urea:ammonia decreased as $\mathrm{N}$ intake and urinary $\mathrm{N}$ excretion were decreasing.

\section{Urinary excretion of purines and creatinine}

The results from Expt 1 (Table 2, Fig. 2) indicate a tendency for both the endogenous allantoin- $\mathrm{N}$ and uric acid- $\mathrm{N}$ excretions to decrease with $\mathrm{N}$ intake. In lambs given liquid diets urinary excretion of allantoin, uric acid and other purines was independent of the diet given (Walker \& Faichney, 1964a). Also in steers maintained on intragastric infusion of nutrients the endogenous excretion of purines (after enzymic conversion to allantoin) was independent of the level of $\mathrm{N}$ infused (Fujihara et al. 1987). It is possible that in Expt 1 part of the effect on endogenous purine metabolism of varying $\mathbf{N}$ intake was due to exogenous purines coming from goat's milk (Johke, 1978). If it is assumed that the exogenous purines were converted to purine bases and excreted in the urine, the tendency for both allantoin and uric acid excretion to decrease with $\mathrm{N}$ intake would disappear.

The allantoin- $N$ excretion in Expt 1 (from 6.8 to $9.4 \mathrm{mg} / \mathrm{kg} \mathrm{W}^{0.75}$ ) was of the same magnitude as those found in experiments with sheep (Walker \& Faichney, 1964 $a$; Walker, 1967; Sibanda, 1982). The amounts of purine derivatives excreted in the urine in Expt 2 were, however, higher than those found in Expt 1. At present there is no explanation for this finding. The very low urinary allantoin- $\mathrm{N}$ excretion $\left(1.7 \mathrm{mg} / \mathrm{kg} \mathrm{W}^{0.75}\right)$ in sheep on intragastric infusion reported by Antoniewicz \& Pisulewski (1982) is in contrast to these findings. 
In Expt 2 there were no significant effects of level of intake on the endogenous allantoin, hypoxanthine and xanthine excretions. Also in previous studies where $\mathbf{N}$ intake was varied, only minor changes in the endogenous excretion of purines were noticed (Walker \& Faichney, 1964a; Fujihara et al. 1987). With the exception of the lowest energy intake in period $1\left(400 \mathrm{~kJ} / \mathrm{kg} \mathrm{W}^{0.75}\right)$ the endogenous uric acid excretion was also independent of level of intake. The increased uric acid- $\mathrm{N}$ excretion at the lowest energy level in period 1 could indicate disturbed purine metabolism in the liver.

Giesecke et al. (1984) reported a reduced excretion of purine catabolites when energy intake increased from 0.25 energy maintenance $(M)$ to $2.0 \mathrm{M}$ in sheep sustained on intragastric infusion. The $\mathrm{N}$ supply in Expt 2 came entirely from goat's milk. In goat's milk the purine $\mathrm{N}$ constitutes 0.006 of the total $\mathrm{N}$ content (Johke, 1978). Taking this exogenous purine contribution into account, and assuming an intestinal digestibility of 0.85 (McAllan, 1982), and a conversion factor of purine- $\mathrm{N}$ to allantoin- $\mathrm{N}$ of 0.45 (J. E. Lindberg, unpublished results), a corrected endogenous allantoin- $\mathrm{N}$ excretion can be calculated. It appears then that in period 1 (Expt 2) increasing energy and $\mathrm{N}$ intakes reduced the endogenous allantoin- $\mathrm{N}$ excretion from $12.3 \mathrm{mg} / \mathrm{kg} \mathrm{W}^{0.75}$ at $400 \mathrm{~kJ}$ GE down to $9.0 \mathrm{mg} / \mathrm{kg}$ $\mathrm{W}^{0.75}$ at $1000 \mathrm{~kJ}$ GE. This was in agreement with the observations of Giesecke et al. (1984). In period 2 (Expt 2) where the kids were on average 7 weeks older, the corrected allantoin$\mathrm{N}$ excretion varied only within $1.3 \mathrm{mg} / \mathrm{kg} \mathrm{W}^{0.75}$ without any relation to level of intake. A similar effect of an exogenous correction may also be expected for the other purine derivatives excreted in the urine. This suggests that at least for very young kids, and probably also other young ruminant species with a high protein retention capacity, the level of energy intake can influence the endogenous purine excretion.

The between-animal variation (as coefficient of variation; CV) in allantoin and uric acid excretion was on average 8.4 and $10.3 \%$ respectively with a range from 1.7 to $16.6 \%$ on the different treatments. A considerably larger between-animal variation (CV 27.6\%) was observed for hypoxanthine excretion with a range from 10.4 to $53.4 \%$ on the different treatments. The variation between animals in excretion of purine derivatives was higher in the very young kids (period 1) than in the older kids (period 2) as shown in Table 4.

In agreement with previous studies (Ørskov \& MacLeod, 1982; Lindberg, 1985) the creatinine excretion remained fairly constant in both experiments irrespective of treatments applied. Also in agreement with previous studies on goats (Lindberg, 1985) the variation between animals in creatinine excretion in the present experiments was rather small $(\mathrm{CV}$ from $2 \cdot 4$ to $3.2 \%$ ). However, on average the creatinine excretion was slightly higher $(14 \%)$ in Expt 2 than that found for male kids in Expt 1. On average the creatinine excretion was slightly higher $(12.4 \mathrm{mg} \mathrm{N} / \mathrm{kg} \mathrm{W})$ in these experiments than that in adult dairy goats $(11.0 \mathrm{mg} \mathrm{N} / \mathrm{kg} \mathrm{W}$ ) of the same breed (Lindberg, 1985). This was probably a reflection of the proportion of lean relative to fat in young growing kids and adult goats.

The urinary excretion of purines in ruminants is related to the intestinal flow of microbial nucleic acids, nucleic acids from the feed and to the metabolism of endogenous nucleic acids (McAllan, 1982; Lindberg, 1985). The findings presented here and those of Fujihara et al. (1987) give support to the opinion that in ruminants the microbial nucleic acids are quantitatively most important for urinary purine excretion (Rys et al. 1975; Antoniewicz et al. 1980; Sibanda, 1982; Lindberg, 1985), with a smaller contribution from endogenous metabolism. At least this should apply to feeding at and above the maintenance level in goats and sheep. Assuming an endogenous excretion of $9 \mathrm{mg}$ allantoin-N/kg $\mathrm{W}^{0.75}$ (Sibanda, 1982; Fujihara et al. 1987; present study) in sheep and goats, and a urinary excretion of $1.2 \mathrm{mg}$ allantoin- $\mathrm{N} / \mathrm{g}$ digestible organic matter (Lindberg, 1985), the endogenous excretion of allantoin- $\mathrm{N}$ at maintenance level of feeding would make up $0 \cdot 20-0.25$ of the total urinary allantoin excretion. Reducing feed intake below maintenance 
would markedly increase the proportion coming from endogenous metabolism. In cattle endogenous urinary excretion of purines appears to be considerably higher than that in sheep and goats (Sibanda, 1982; Lindberg, 1985; Fujihara et al. 1987; present study). Assuming an endogenous urinary excretion of $25 \mathrm{mg}$ total purine- $\mathrm{N} / \mathrm{kg} \mathrm{W} \mathrm{W}^{0.75}$ in cattle (Sibanda, 1982; Fujihara et al. 1987) with 0.70 as allantoin (present study) and $1.2 \mathrm{mg}$ allantoin- $\mathrm{N} / \mathrm{g}$ digestible organic matter, it is estimated that 0.30 to 0.35 of the total urinary allantoin excretion is of endogenous origin in cattle. Despite the uncertainty about the contribution of feed nucleic acids to urinary purine excretion (McAllan, 1982), which requires further research, the findings presented here support the validity of using urinary purine excretion to quantify the intestinal flow of microbial protein in ruminants.

\section{REFERENCES}

Agricultural Research Council (1980). The Nutrient Requirements of Ruminant Livestock. Farnham Royal: Commonwealth Agricultural Bureaux.

Antoniewicz, A. M., Heinemann, W. W. \& Hanks, E. M. (1980). The effect of changes in the intestinal flow of nucleic acids on allantoin excretion in the urine of sheep. Journal of Agricultural Science, Cambridge 95 , $395-400$.

Antoniewicz, A. M., Heinemann, W. W. \& Hanks, E. M. (1981). Effect of level of feed intake and body mass on allantoin excretion and the allantoin to creatinine ratio in the urine of sheep. Roczniki Naukowe Zootechniki $T$ 8, 49-65.

Antoniewicz, A. M. \& Pisulewski, P. M. (1982). Measurement of endogenous allantoin excretion in sheep urine. Journal of Agricultural Science, Cambridge 98, 221-223.

Balch, C. C. (1967). Problems in predicting the value of non-protein nitrogen as a substitute for protein in rations for farm animal ruminants. World Review of Animal Production 3, 84-91.

Blaxter, K. L. \& Wood, W. A. (1951). The nutrition of the young Ayrshire calf. 1. The endogenous nitrogen and basal energy metabolism of the calf. British Journal of Nutrition 5, 11-25.

Ciszuk, P. \& Lindberg, J. E. (1985). Total nitrogen retention in lactating goats in relation to digested nitrogen and estimated absorption of amino acids. Acta Agriculturae Scandinavica 25, Suppl. 163-176.

Dunn, O, J. \& Clark, V. A. (1974). Applied Statistics Analysis of Variance and Regression. New York: John Wiley.

Fattet, I., Hovell, F. D., Deb., Ørskov, E. R., Kyle, D. J., Pennie, K. \& Smart, R. I. (1984). Undernutrition in sheep. The effect of supplementation with protein on protein accretion. British Journal of Nutrition 52 , 561-574.

Fujihara, T., Ørskov, E. R., Reeds, P. J. \& Kyle, D. J. (1987). The effect of protein infusion on urinary excretion of purine derivatives in ruminants nourished by intragastric nutrition. Journal of Agricultural Science, Cambridge 109, 7-12.

Giesecke, D., Stangassinger, M. \& Tiemeyer, W. (1984). Nucleic acid digestion and urinary purine metabolites in sheep nourished by intragastric infusions. Canadian Journal of Animal Science 64, Suppl., 144-145.

Hovell, F. D. Deb., Ørskov, E. R., Grubb, D. A. \& MacLeod, N. A. (1983a). Basal urinary nitrogen excretion and growth response to supplemental protein by lambs close to energy equilibrium. British Journal of Nutrition 50, 173-187.

Hovell, F. D. Deb., Ørskov, E. R., MacLeod, N. A. \& McDonald, I. (1983b). The effect of changes in the amount of energy infused as volatile fatty acids on the nitrogen retention and creatinine excretion of lambs wholly nourished by intragastric infusion. British Journal of Nutrtion 50, 331-343.

Johke, T. (1978). Nucleotides of mammary secretions. In Lactation; a Comprehensive Treatise, vol. 4, pp. 513-522. [B. L. Larsson, editor]. New York: Academic Press.

Lindberg, J. E. (1985). Urinary allantoin excretion and digestible organic matter intake in dairy goats. Swedish Journal of Agricultural Research 15, 31-37.

Lindberg, J. E., Bristav, H. \& Manyenga, A. R. (1988a). Excretion of purines in the urine of sheep in relation to duodenal flow of microbial protein. Swedish Journal of Agricultural Research (In the Press.)

Lindberg, J. E. \& Jansson, C. (1988). A rapid automated analysis of allantoin in ruminant urine. Swedish Journal of Agricultural Research (In the Press.)

Lindberg, J. E., Manyenga, A. R. \& Karlsson, A. R. (1988 b). Equipment for the Collection of Faeces and Urine in Growing Goat Kids. Swedish University of Agricultural Sciences, Department of Animal Nutrition and Management, Report 168.

Lindgren, E. (1980). Estimation of Energy Losses in Methane and Urine by Ruminants. Swedish University of Agricultural Sciences, Department of Animal Nutrition, Report 47.

McAllan, A. B. (1982). The fate of nucleic acids in ruminants. Proceedings of the vutrition Society 41 , 309-317. 
McGregor, B. A. (1980). Growth and composition of wether goat carcasses. Animal Production in Australia 13, 345-348.

Nordisk Metodikkommitté för livsmedel (1976). no. 16, 3rd ed.

Ørskov, E. R. \& MacLeod, N. A. (1982). The determination of the minimal nitrogen excretion in steers and dairy cows and its physiological and practical implications. British Journal of Nutrition 47, 625 ...636.

Ørskov, E. R., MacLeod, N. A., Fahmy, S. T. M., Istasse, L. \& Hovell, F. D. Deb. (1983). Investigation on nitrogen balance in dairy cows and steers nourished by intragastric infusion. Effects of submaintenance energy input with or without protein. British Journal of Nutrition 50, 99-107.

Rys, R., Antoniewicz, A. \& Maciejewicz, J. (1975). Allantoin in urine as an index of microbial protein in the rumen. In Tracer Studies on Non-protein Nitrogen in Ruminants, vol. 2, pp. 95-98. Vienna: IAEA.

SAS (1982). SAS User's Guide: Statistics. Cary, NC:SAS Institute.

Sibanda, S. (1982). The excretion of allantoin and other urinary nitrogen compounds by ruminants in relation to microbial protein production and dietary energy and protein. MSc Thesis, University of Aberdeen.

Storm, E., Ørskov, E. R. \& Smart, R. (1983). The nutritive value of rumen micro-organisms in ruminants. 2. The apparent digestibility and net utilization of microbial $\mathrm{N}$ for growing lambs. British Journal of Nutrition $\mathbf{5 0}$, 471-478.

Technicon Instruments Co. Inc. (1972). Technicon Clinical Method No. 01. Basingstoke: Technicon Instruments.

Technicon Instruments Co. Inc. (1977a). Technicon Industrial Method no. $334-74 \mathrm{~W} / \mathrm{B}^{+}$. Basingstoke: Technicon Instruments.

Technicon Instruments Co. Inc. (1977b). Technicon Industrial Method no. SF4-011FC7. Basingstoke: Technicon Instruments.

Topps, J. H. \& Elliot, R. C. (1965). Relationship between concentrations of ruminal nucleic acids and excretion of purine derivatives by sheep. Nature 205, $498-499$

Vercoe, J. E. (1976). Urinary allantoin excretion and digestible dry-matter intake in cattle and buffalo. Journal of Agricultural Science. Cambridge 86, 613-165.

Walker, D. M. (1967). Nitrogen balance studies with the milk-fed lamb. 6. Effect of starvation and realimentation. British Journal of Nutrition 21, 289-308.

Walker, D. M. \& Faichney, G. J. (1964a). Nitrogen balance studies with the milk-fed lamb. 2. The partition of urinary nitrogen and sulphur. British Journal of Nutrition 18, 201-207.

Walker, D. M. \& Faichney, G. J. (1964b). Nitrogen balance studies with the milk-fed lamb. 3. Effect of different nitrogen intakes on growth and nitrogen balance. British.Journal of Nutrition 18, 295.

Watts, R. W. E. (1980). Biochemical aspects of nucleic acid metabolism. In: European Association of Animal Production Publication no. 27, pp. 106-117. Braunschweig: Federal Republic of Germany.

Young, E. G. \& Conway, C. F. (1942). On the estimation of allantoin by the Rimini-Schryver reaction. Journal of Biological Chemistry 142, 839-852. 